\title{
頭蓋外椎骨動脈狭窄・閉塞性疾患に対する血行再建術
}

\author{
小笠原 邦 昭 小川彰
}

\section{Reconstructive Surgery for Occlusive Disease of Extracranial Vertebral Artery \\ by}

Kuniaki Ogasawara, M.D., and Akira Ogawa, M.D.

from

Department of Neurosurgery, Iwate Medical University

Recently, the number of patients with atherosclerotic vertebrobasilar occlusive disease has increased. Various surgical treatments such as vertebral endarterectomy, vertebral to carotid transposition, vertebral to subclavian transposition or vertebral to carotid bypass using graft have been reported for extracranial vertebral artery occlusive disease. However, which technique should be applied to each pathological condition has not been sufficiently studied.

Based on our experiences, vertebral to subclavian artery transposition is the best vascular reconstruction for cases of atherosclerotic stenosis at the origin of the vertebral artery when severe atherosclerotic lesions of the subclavian artery are absent. There are the following reasons for the opinion: serious surgical complications are rarely encountered, temporary occlusion of the common carotid artery is unnecessary, the cerebral blood pathway after surgery is natural, and the long-term patency rate of the anastomosis is good.

On the other hand, external carotid artery-vertebral artery bypass using saphenous vein graft is the better vascular reconstruction than superficial temporal artery-superior cerebellar artery anastomosis for cases of occlusion of the vertebral artery at its origin with distal portion of the artery perfused by the collaterals.

(Received June 28, 2002; accepted August 7, 2002)

Key words : extracranial vertebral artery occlusive disease, vertebral to subclavian artery transposition, external carotid artery-vertebral artery bypass

Jpn J Neurosurg (Tokyo) $11: 783-788,2002$

\section{はじめに}

近年, 生活習慣病の増加および非侵襲的診断法の発達 により, 本邦においても頭蓋外頸部動脈閉塞性病変の頻 度が急激に增加している. なかでも椎骨一脳底動脈系病 変の占める割合は少なくないことが, 以前より指摘され ている3）。 また, 椎骨一脳底動脈系の一過性脳虚血発作例 では, stroke への移行率が anterior circulation のものと変 わらないばかりか, 1 年以内ではむしろ高いとするもの
がある ${ }^{8)}$.さらに, いったん stroke に移行した場合の死 亡率は, anterior circulation に比し，かなり高率であると する報告もみられる ${ }^{10)}$. それにもかかわらず，本邦にお いてはこの病変に対する外科的血行再建術の報告はまれ であり，ポピュラーな手技とはいえない. 、本稿では, 頭蓋外椎骨動脈狭窄・閉塞性疾患に対する 血行再建術につき，著者らの考えも含め，概説する．

岩手医科大学脳神経外科 $/ \overline{\mathrm{T}} 020-8505$ 盛岡市内丸 19-1〔連絡先：小笠原邦昭〕

Address reprint requests to: Kuniaki Ogasawara, M.D., Department of Neurosurgery, Iwate Medical University, 19-1 Uchimaru, Morioka-shi, Iwate 020-8505, Japan 


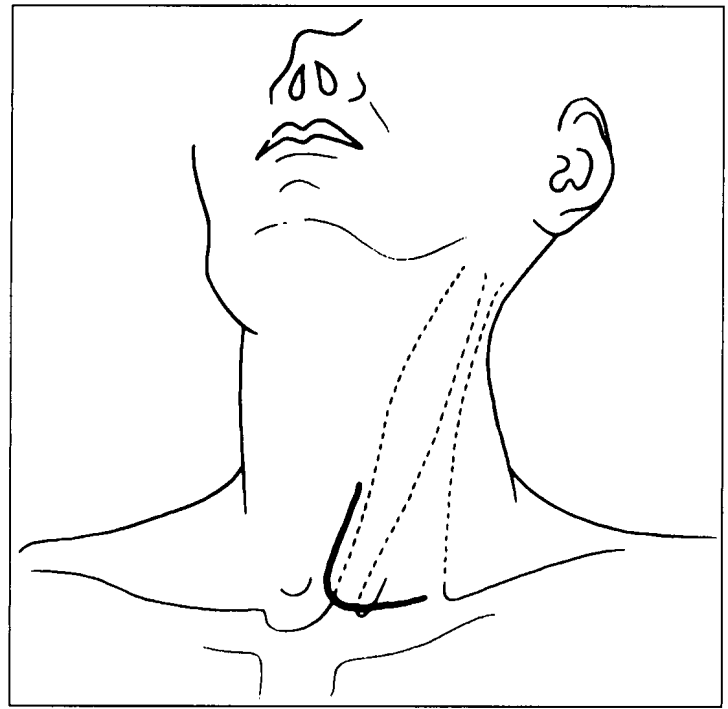

Fig. 1 Position and skin incision

\section{椎骨動脈の局所解剖と閉塞性病変の原因}

椎骨動脈は以下のように 4 つの segment に分けるこ とができる2).

First segment：鎖骨下動脈を出て長頸筋と前斜角筋の 間を走り， $\mathrm{C}_{6}$ 横突孔に入るまでの部分.

Second segment：axis の横突孔に入るまでの部分.

Third segment：axis から出て側後方に向かい, atlas の 横突孔を経て atlanto-occipital menbrane に至る部分.

Fourth segment：硬膜-クモ膜下にある部分.

Second segment 以降末梢の頭蓋外椎骨動脈において は, 骨成分あるいは軟部組織による外からの圧迫が狭窄, 閉塞の原因となるが，頻度的にはまれである．First segment, 特に起始部における動脈硬化性病変は, 頭蓋外椎 骨動脈の狭窄・閉塞性病変の原因として圧倒的に多い.

\section{椎骨動眽起始部狭窄症に対する血行再建術}

\section{1 手術適応}

椎骨一脳底動脈系の一過性脳虚血発作あるいは完成卒 中を呈し, 脳血管撮影上, 優位側椎骨動脈起始部の 70〜 75\%以上の狭窄を認めるかあるいは，両側椎骨動脈起始 部の 50 〜 $75 \%$ 以上の狭窄を認める症例とされてい る1) 13).

\section{2 椎骨動眽起始部血栓内膜剝離術}

血栓内膜剝離術は，初期には椎骨動脈起始部狭窄症の 血行再建術の主流であった ${ }^{411) 14)}$ ．この手術のアプロー チは, 開胸するもの, 胸骨切開から縱隔経由のもの, 鎖 骨切除を行うもの，鎖骨上経由などさまざまであり，ま
た血栓内膜剝離術も，鎖骨下動脈の動脈切開から行うも のや椎骨動脈の動脈切開から行うものなどが報告され た．しかし，椎骨動脈は鎖骨下動脈あるいは頸動脈に比 して動脈壁が薄くて弱く, primary suture が困難である こと, 椎骨動脈は血管径が小さく内膜㔀離後も十分な搪 張が得られず, patch graft の使用が必要となることなど から, 椎骨動脈のみの切開による内膜剝離術は行われな くなってきた。一方, 鎖骨下動脈切開からの椎骨動脈起 始部内膜剝離術においても, 椎骨動脈分岐部が低位の症 例では, 鎖骨上経由では椎骨動脈の内膜剶離術が困難で あり，開胸や胸骨切開，鎖骨除去が必要となり，次に述 べる transposition に比して侵熋が大きくなることから 徐々に行われなくなってきた。

\section{3 椎骨動眽起始部 transposition}

この手術法には vertebral to carotid transposition と vertebral to subclavian transpositionの 2 つがある ${ }^{5) 13)}$. 前 者の方が椎骨動脈起始部狭窄症に対する血行再建術の主 流となっているが，その理由として以下の 2 点が挙げら れる. 1 つには, この部の手術が大動脈や無名動脈, 鎖 骨下動脈などの大動脈病変の手術から, 主に血管外科医 の手によって発達してきたこと, またもう1つは, 欧米 においては椎骨動脈起始部狭窄症の多くは鎖骨下動脈硬 化性病変と合併しており, donor としての鎖骨下動脈の 使用が困難な症例が少なくなかったことである.

しかし，本邦では鎖骨下動脈硬化性病変の合併は少な く, 吻合血管の donor として鎖骨下動脈を使うことに大 きな問題はない.さらに, vertebral to subclavian transpositionの最大の利点は, 総頸動脈の遮断を要せず, 最低限 の脳灌流血管の遮断で手術が可能なことである。 また, 吻合後の血流路が生理的であることの利点もあり，鎖骨 下動脈に硬化性病変がない場合は, 本法を手術の第一選 択とすべきであると考えられる。

\section{Vertebral to subclavian transposition の手術 手技 ${ }^{13)}$}

仰臥位で上体を挙上し，頭部は下げて術野が最も高い 体位をとる. Fig. 1 のように皮膚切開後，その直下で platisma を切断する. 次いで, 胸鎖乳突筋の胸骨頭と鎖 骨頭を確認し，この間を剝離分離し，胸骨頭を腱の部分 で後に再縫合できるように結禁して切断する．胸骨頭を 翻転すると, 内側に musculus sternothyreoideus, musculus sternohyoideus, 外側に胸鎖乳笑筋の鎖骨頭，下辺は 鎖骨の三辺に囲まれた三角が確認され，この部は疎な脂 肪組織とリンパ節からなっている。この部を䡈離し，小 
動脈を確認する。この動脈は thyreocervical trunk であ りこれを中枢側に向かって剝離すると鎖骨下動脈が確 認される。

本手術では総頸動脈の剝離は必要なく，また胸管，迷 走神経，反回神経などの位置関係からみて，頸静脈の外 側からの侵入が安全である．鎖骨下動脈を中枢側および 末梢側に㔀離しつつ, これから分岐する internal thoracic artery, costocervical trunk を剥離する. costocervical trunk は鎖骨下動脈の背側から分岐しているので注意を 要する，最後に椎骨動脈の剝離を行う（Fig. 2)。この剝 離は第 6 頸椎横突孔まで行い, さらに鎖骨下動脈からの 分岐直後で横断する星状神経節を部分的に切断し, 椎骨 動脈に可動性をもたせる．鎖骨下動脈の背側の剝離は鎖 骨下動脈の可動性を増し，血管背側にガーゼを敷くこと により，吻合の術野を浅くすることができる。これは， 椎骨動脈に余裕をもたせ吻合を容易にするばかりでな く，吻合後ガーゼを除去すると鎖骨下動脈の挙上が解除 され，椎骨動脈が下方に牽引され，椎骨動脈を蛇行なく 走行させるのに有用である.

internal thoracic artery, thyreocervical trunk, costocervical trunk を遮断し，次いで末梢側の鎖骨下動脈，中枢側 鎖骨下動脈，椎骨動脈を遮断する，分枝の遮断には脳動 脈溜用の clip を用いる。鎖骨下動脈の遮断には 90 度アン グルの血管針子が有用である．また術中の不測の出血に 借え，中枢側の鎖骨下動脈に vessel tape をかけておく。

椎骨動脈を起始部にて結紮切断し，末梢側の椎骨動脈 の断端を形成する。このとき動脈硬化性病変により内膜 肥厚が著しい場合には, 椎骨動脈の断端部の内膜剝離術 を追加する（Fig. 3）。鎖骨下動脈は椎骨動脈の太さに合 わせ，血管パンチを用いてパンチアウトする，吻合系は 7-0ナイロンかゴアテックスを用いる．最も深い対側に 2 針の stay suture を並べて置き，互いに離れるように連 続縫合を行う。円周 $1 / 3$ まで連続縫合を終了したら,こ の部に stay suture を置き,最後に手前の $1 / 3$ の縫合を行 う.

鎖骨下動脈末梢部の遮断を解除し，次いで椎骨動脈を 解除後再遮断する。中枢側鎖骨一下動脈の遮断を解除し， 最後に椎骨動脈の遮断を解除する（Fig. 4, 5).

5. Vertebral to subclavian transposition $の$ 周術 期合併症，遠隔転帰および再狭窄率

1. 周術期合併症

椎骨動脈剝離の際に, 鎖骨下動脈からの分岐直後で横 断する星状神経節を部分的に切断しなければならない。

このため術直後に全例に Horner 症候群を認める。また，

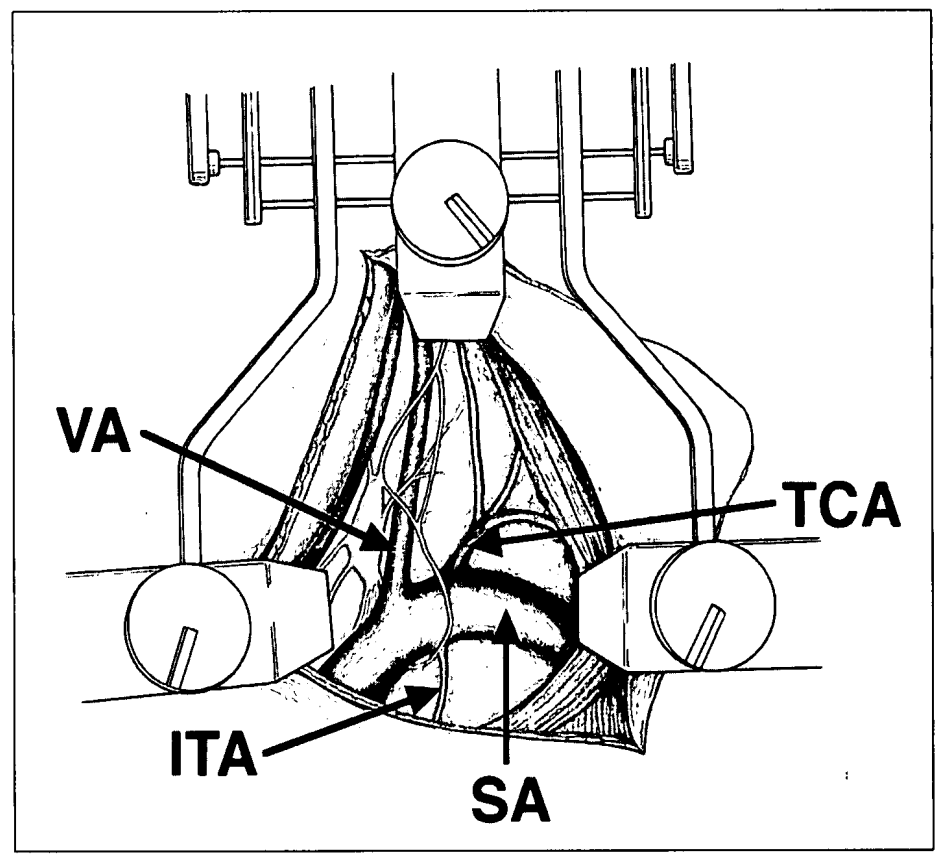

Fig. 2 Exposure of the subclavian (SA), vertebral (VA), internal thoracic (ITA) and thyreocervical arteries (TCA)

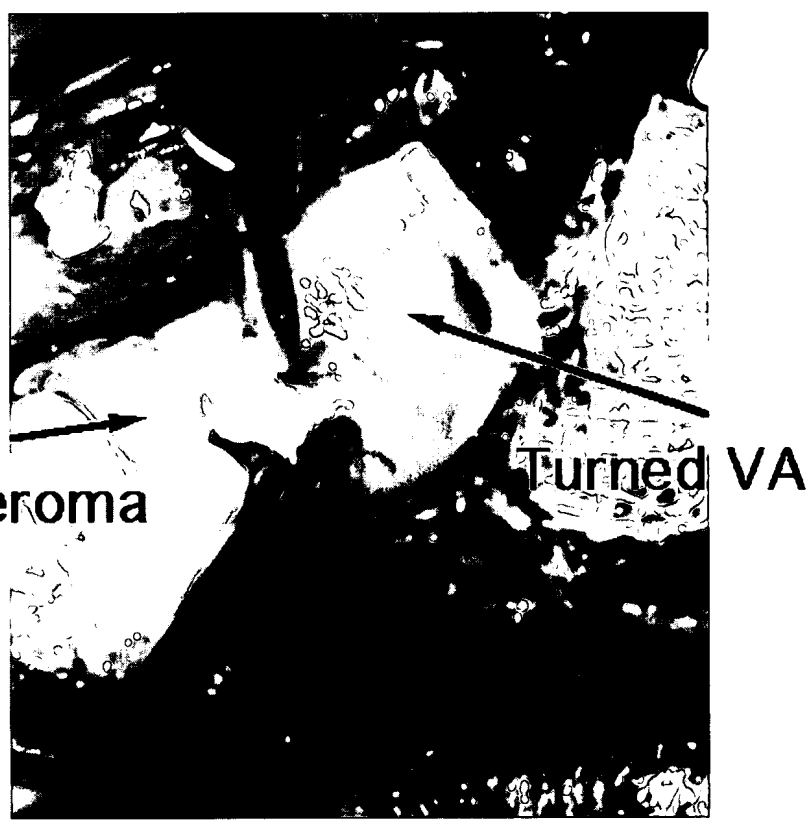

Fig. 3 Techniques of the atheroma removal in cases with extended stenosis of the vertebral artery

左側の手術にて胸管損傷によるリンパ漏が出現すること がある．リンパ漏が出現した場合，漏の自然閉鎖は望め ないので, 早期の再手術が必要である。 そのほかまれな がら反回神経，腕神経などの麻㽻が認められることがあ るが，直接損傷でなければ一過性である．椎骨動脈遮断 による脳虚血合併症については，われわれは経験してい ない. 


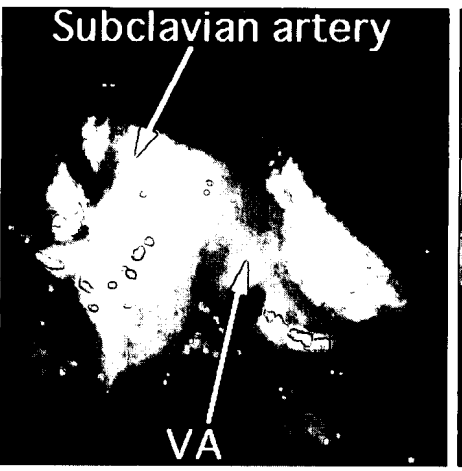

A : Before trasposition

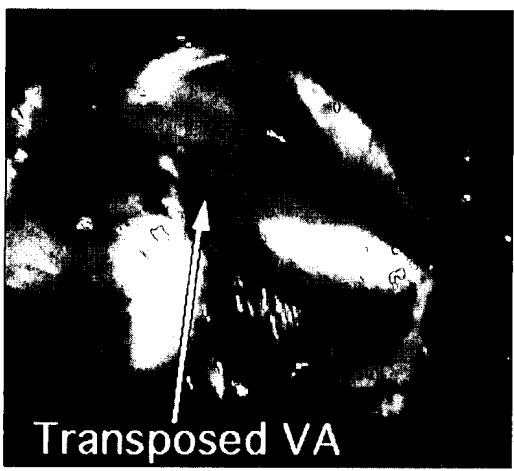

B : After transposition

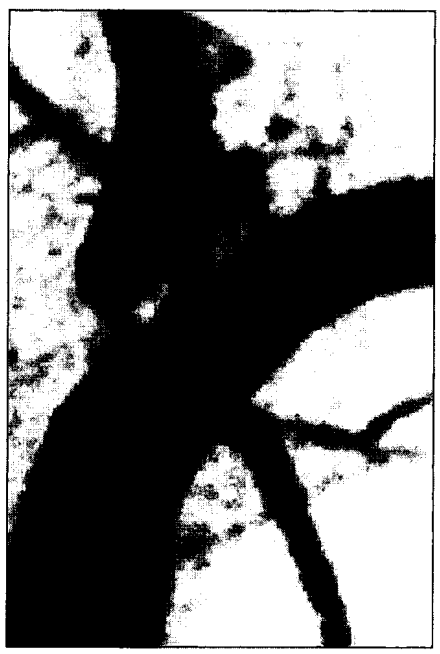

A : Before surgery

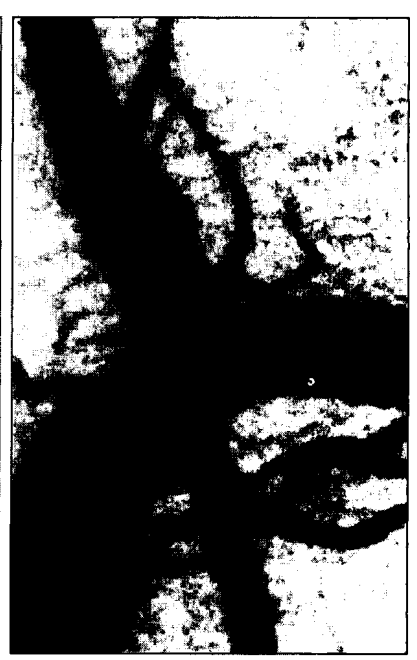

B : After surgery

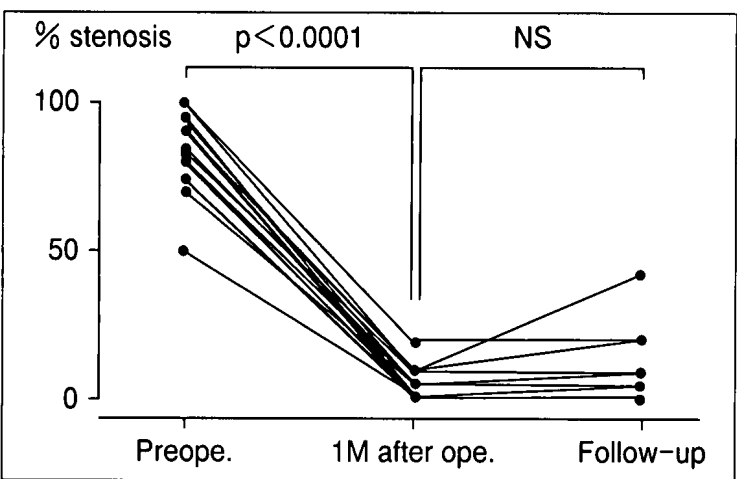

Fig. 6 Changes of degree of stenosis before and after surgery

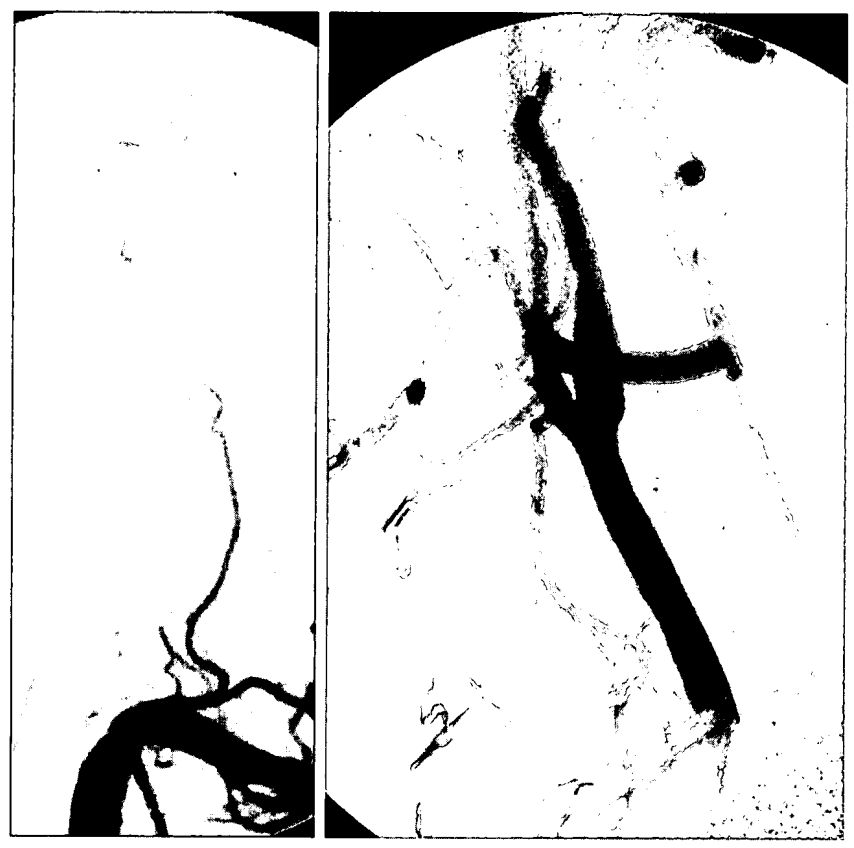

$\overline{\mathrm{A} \mid \mathrm{B}}$ Fig. 8 Intraoperative angiograms of external carotid artery-vertebral artery bypass using saphenous vein graft

A : Vertebral artery-saphenous vein anastomosis

B : Saphenous vein-external carotid artery anastomosis
Fig. 5 Angiograms of a patient with stenosis of the left vertebral artery at its origin

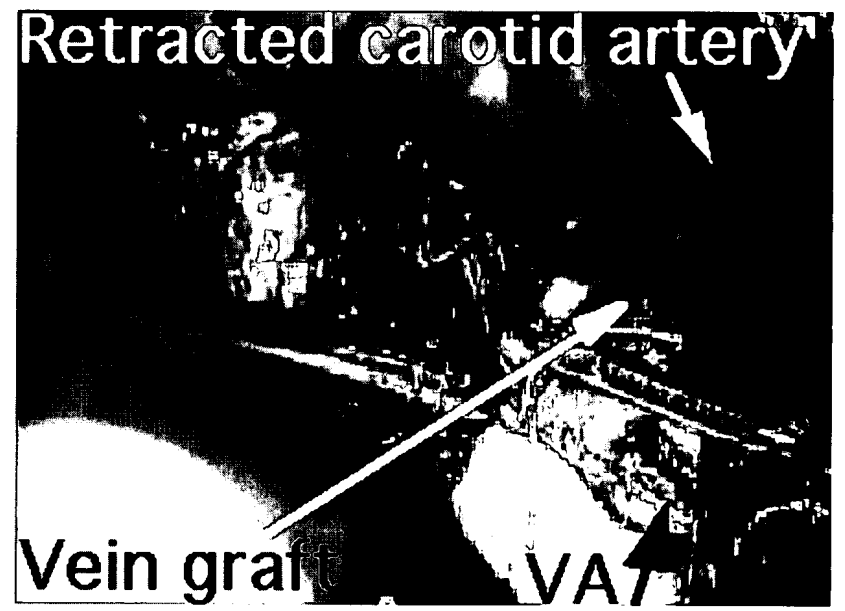

$\frac{\mathbf{A}}{\mathbf{B}}$

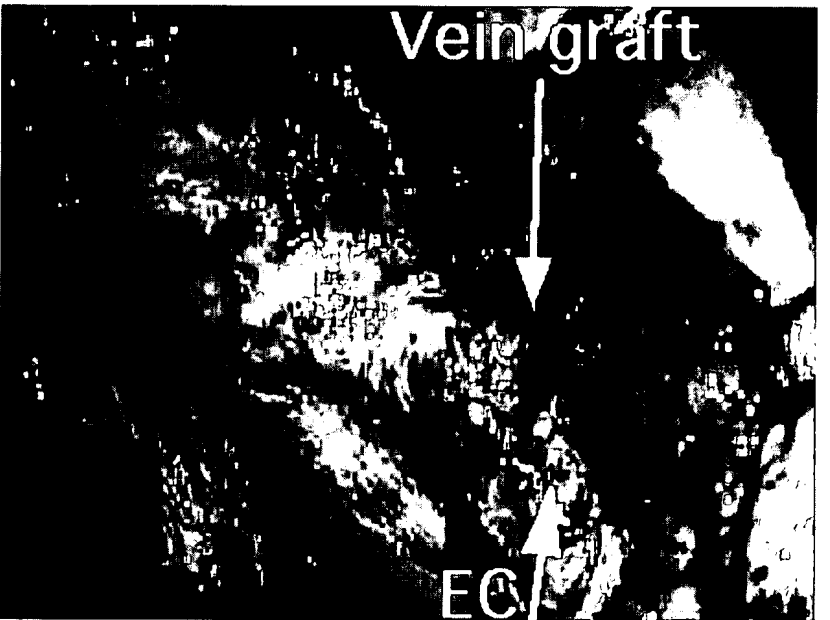

Fig. 7 Angiograms of a patient with occlusion of the left vertebral artery at its origin

A : Before surgery. Distal portion of the left vertebral artery is perfused by the muscle branches of the costocervical trunk preoperatively.

B : After surgery. Postoperative left common carotid angiogram shows excellent filling of the vertebral arterty via the bypass graft. 


\section{2. 遠隔転帰}

遠隔転㷌については，まとまった報告がないため，わ れわれの成績を述べる ${ }^{12)}$. 6 力月〜 14 年（平均 7.8 年）

の追跡期間で 53 例中 7 例（13\%）が死亡した．死因の 内訳は心筋梗塞 3 例, 悪性新生物 2 例, 腎不全 1 例, 糖 尿病 1 例で, 頸部頸動脈内膜剝離術後と同様に心筋梗塞 による死亡が最多であった．脳虚血症状の再発は 3 例 （5.7\%）に認められた。いずれも内頸動脈灌流域の脳虚 血によるものであり，椎骨一脳底動脈領域の脳虚血症状 の再発は認められなかった。

\section{3. 再狭窄率}

NASCET の狭窄度測定法を椎骨動脈起始部に適応し, われわれの 43 例で再狭窄率を検討してみた (Fig. 6)。術 後 1 力月では全例狭窄度は $25 \%$ 以下に改善しており, 術 後 6 力月 8 年 (平均 3.6 年) の時点でも, 統計学的に 有意な狭窄度の変化はなく, 1 例のみが $40 \%$ の狭窄度を 呈したのみであった。このことから，本法の再狭窄率は 正常に低いものと考えられる。

\section{椎骨動眽起始部閉塞症に対する血行再建術}

\section{1 手術適応亡術式選択}

椎骨-脳底動脈系の一過性脳虚血発作あるいは完成卒 中，とくに繰り返す薬物抵抗性のめまいはよい適応であ る. 脳血管撮影上，優位側椎骨動脈の閉塞あるいは，対 側椎骨動脈の狭窄・閉塞を伴う椎骨動脈の閉塞を適応と する。

椎骨動脈閉塞症に対する血行再建術の術式を選択する 際には，その閉塞部位が問題となる。すなわち閉塞部位 が頭蓋内であれば，浅側頭動脈一上小脳動脈吻合術が選 択される。しかし，筋枝等を介して閉塞部位より末梢の 椎骨動脈 second segment が造影される椎骨動脈閉塞症 においては（Fig. 7)，「脳の血行再建はできうるかぎり中 枢側（心臟側）から行う」という原則に従い，椎骨動脈 に対し順行性の血流が得られる外頸動脈一頸部椎骨動脈 バイパス術を選択すべきと考える。

\section{2 外頸動脈-頸部椎骨動眽バイパス術の手術手枝}

通常の頸部頸動脈内膜剝離術の体位, 皮膚切開を行う。 総頸動脈を露出, 永離後, 外頸動脈を㓦離し, donor と しての吻合の準備をしておく，次いで頸動脈を内側に圧 排し, 開存し健常部と思われる頸椎横突孔前面の長頸筋, 鞋帯を除去し，横突孔を開放する，さらに横突孔の中を 走っている椎骨動脈周囲の静脈叢を除去する．このとき 静脈叢よりかなりの出血がみられる. recipient としての
椎骨動脈に対する吻合の準備後, graft として用いる伏在 静脈の中枢側と椎骨動脈とを吻合する (Fig. 8). その後, 伏在静脈の末梢側と外頸動脈とを吻合する（Fig. 8)。こ のとき，吻合部がねじれないように，なるべく外頸動脈 の裏に吻合する．また，graft とねじれ・圧迫を防ぐ目的 で，人工血管で graft を被うことも必要である.

\section{3 外頸動眽-頸部椎骨動眽バイパス術の周術期合 併症および遠隔転帰}

われわれは 7 例に対し本法を行っているが，周術期合 併症は認めなかった．また，術後は全例にバイパスの開 存とバイパスからの椎骨動脈末梢部の良好な造影を認め ている（Fig. 7)。しかし，その長期開存率については現 在のところ不明である。

\section{おわりに}

頸部頸動脈狭窄症に対する内膜剝離術は, evidence の ある治療法として確立されている ${ }^{9)}$ ．また頸動脈閉塞症 に対するバイパス術も，その有効性についての共同研究 が現在行われている ${ }^{6) 7)}$. しかし, 頸部椎骨動脈狭窄・閉 塞性病変に対する外科治療に関しては, stenting も含め evidence はない. 今後, さらにこの病変が増加すること が予想され，外科治療の有用性の有無を証明する必要が でてくるものと思われる.

\section{文 献}

1) Berguer R, Flynn LM, Kline RA, Caplan L: Surgical reconstruction of the extracranial vertebral artery: Management and outcome. J Vasc Surg 31:9-18, 2000.

2) Carney AL: Vertebral artery surgery: Historical development, basic concepts of brain hemodynamics, and clinical experience of 102 cases: Diagnosis and treatment of brain ischemia. in Carney AL, Anderson EM (eds): Advance in Neurology, vol. 30. New York, Raven Press, 1981, pp. 249282.

3) Cartilidge NEF, Whisnant JP, Elveback LR: Carotid and vertebral-basilar transient ischemic attacks: A community study. Minnesota Mayo Clin Proc 52: 117-120, 1997.

4) Cormier JM, Laurian C: Surgical management of vertebral-basilar insufficiency. $J$ Cardiovasc Surg 17:205223, 1976.

5) Edwards WH, Mulherin JL Jr: The surgical approach to significant stenosis of vertebral and subclavian arteries. Surgery 87:20-28, 1980.

6) JET Study Group: Japanese EC-IC Bypass Trial (JET Study) : study design と中間解析結果. 脳卒中の外科 30: 97-100, 2002.

7) JET Study Group: Japanese EC-IC Bypass Trial (JET Study): 中間解析結果 (第二報)。脳卒中の外科 (in press)

8) Jones HR Jr, Millikan CH, Sandok BA: Temporal profile 
(clinical course) of acute vertebrobasilar system cerebral infarction. Stroke 11: 173-177, 1980.

9) Moore WS, Barnett HJ, Beebe HG, Bernstein EF, Brener BJ, Brott T, Caplan LR, Day A, Goldstone J, Hobson RW II, Kempczinski RF, Matchar DB, Mayberg MR, Nicolaides AN, Norris JW, Ricotta JJ, Robertson T, Rutherfond RB, Thomas D, Toole JF, Trout HH III, Wiebers DO : Guidelines for carotid endarterectomy: A multidisciplinary consensus statement from the Ad Hoc Committee, American Heart Association. Stroke 26: 188-201, 1995.

10) Moufarrij NA, Little JR, Furlan AJ, Williams G, Marzewski DJ: Vertebral artery stenosis: Long-term follow-up. Stroke 15:260-263, 1984.
11) Natali J, Maraval M, Kieffer E : Surgical treatment of stenosis and occlusion of the internal carotid and vertebral arteries. J Cardiovasc Surg 13:4-15, 1972.

12）小笠原邦昭, 桑田知之, 三浦一之, 紺野 広, 笹生昌之, 奥口 卓, 鈴木倫保, 小川 彰, 桜井芳明：椎骨動脈起始 部狭窄病変に対する vertebral to subclavian transposition の long term outcome. The Mt. Fuji Workshop on CVD 17 : 199-201, 1999.

13) Ogawa A, Yoshimoto $T$, Sakurai $Y$ : Treatment of proximal vertebral artery stenosis : Vertebral to subclavian transposition. Acta Neurochir 112 : 13-18, 1991.

14) Roon AJ, Ehrenfeld WK, Cooke PB, Wylie EJ : Vertebral artery reconstruction. Am J Surg $138: 29-36,1979$.

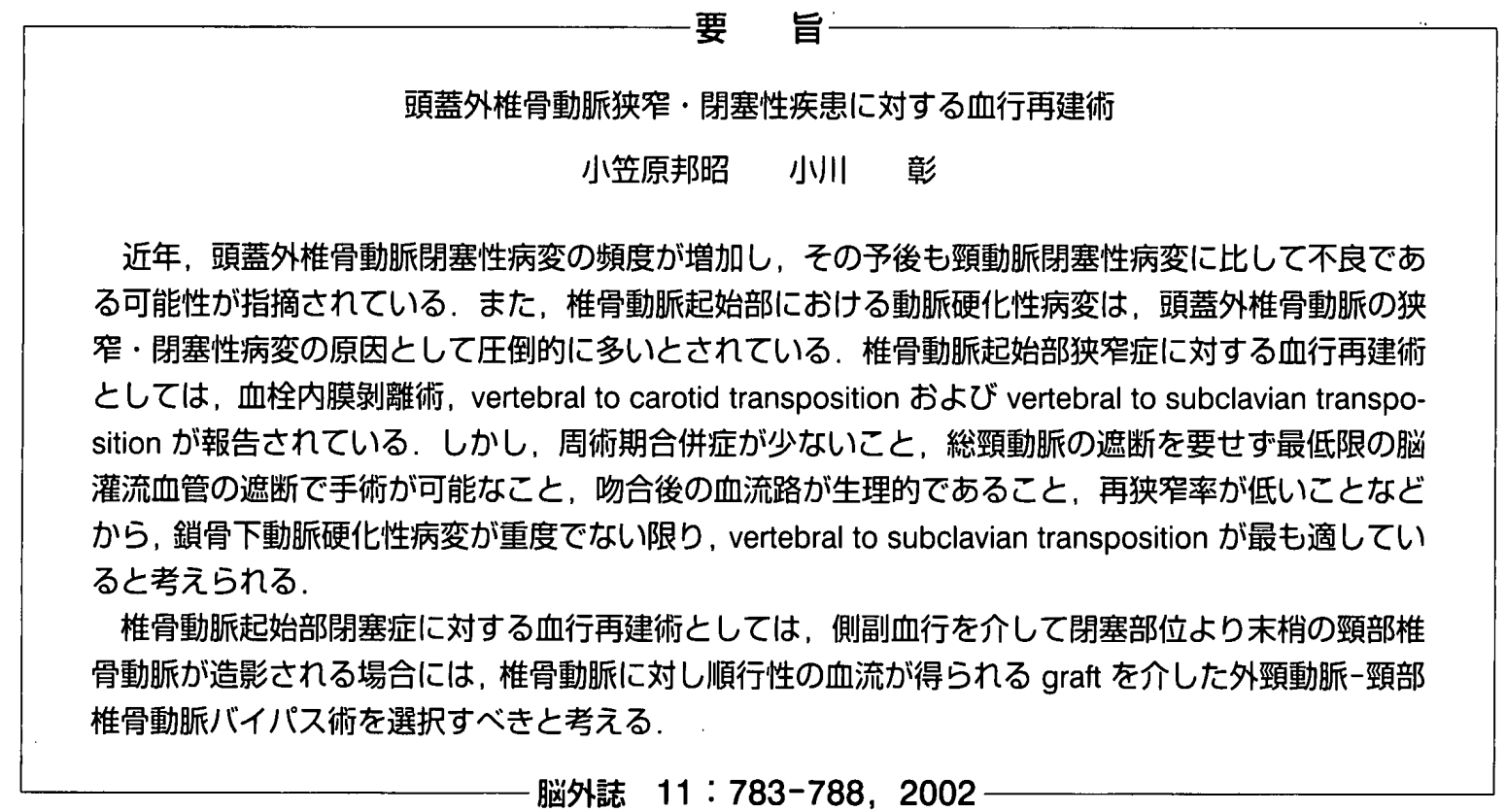

\section{「読者の意見 (Letters to the Editor)」原稿募集のお知らせ}

本誌では「読者の意見 (Letters to the Editor)」欄 を設けています。読者交流の場として意見交換にご利用 いただきたく，下記の要領で編集室宛に原稿をお寄せく ださい.

趣 旨：(1)揭載論文に対する意見，(2)編集方針に対す る意見，希望などを掲載いたします。(1)関 しては著者側からのコメントも揭載いたしま व.

執筆内容：(1)本文は図表も含め 1,200 字以内 (文献は 3 個以内，写真·図·表は 1 個以内とし，关の 数に応じて本文を減じてください)，(2)筆者
名, 所属を明記, (3)著者側からのコメントは 600 字以內

採否：編集委員会で決定いたします。不採用の場合 は速やかに連絡いたしますが，理由はお知ら せいたしません，また，採否のいかんにかか わらず，原稿は返却いたしません。

光の他：論文掲載後 3 力月以内に意見をお寄せくださ い. 文章は書簡の形式（口語体）としてくだ さい，採用の場合は掲載誌 1 部をお送りいた します。

「脳神経外科シャーナル」編集委員会 